\title{
A Comparative Analysis of Objective Statements in Syllabi for English Teacher education in Finland and South Korea
}

Kyong, Jin

2021-06-01

Kyong , J , Hilden , R \& Lee , J 2021, ' A Comparative Analysis of Objective Statements in Syllabi for English Teacher education in Finland and South Korea ' , Korean Journal of Comparative Education , vol. 31 , no. 2 , pp. 39-64 . https://doi.org/10.20306/kces.2021.31.2.39

http://hdl.handle.net/10138/333758

https://doi.org/10.20306/kces.2021.31.2.39

cc_by_nc_sa

publishedVersion

Downloaded from Helda, University of Helsinki institutional repository.

This is an electronic reprint of the original article.

This reprint may differ from the original in pagination and typographic detail.

Please cite the original version. 


\title{
A Comparative Analysis of Objective Statements in Syllabi for English Teacher Education in Finland and South Korea*
}

\author{
Lee, Jinkyong(Professor, Daegu Catholic University) \\ Hilden, Raili(Associate professor, University of Helsinki)
}

$\langle$ Summary >

\begin{abstract}
Purpose: This paper compared the curricula of English teacher education programs in Finland and Korea. The purpose of the study is two folds: to explore what the professional teacher competencies of both countries pursue and how they are reflected in course syllabi.
\end{abstract}

Methods: Data are collected by analyzing course syllabi presented on web pages of each university where the researchers are teaching. Specifically, the study analyses course objective statements using the teacher competence framework, which consists of knowledge, skills, and dispositions.

Results: The results show that the knowledge domain is more emphasized in Korean English teacher education courses, while skills prevail in the Finnish program. The different value each teacher education curriculum places on the teaching practicum might produce the result. The Finnish English teacher program integrates skill domains into extensive practice courses, while the practice is more modest in the Korean program. The domain of values and dispositions seems to have less importance in both countries' curricula, although dispositions are fundamental in teacher competencies.

Conclusion: Both countries' teacher education needs to achieve a balance between knowledge, skills, and disposition, which are large categories of teacher competence, as well as among elements within each domain. In particular, it seems necessary to deviate from the general pedagogical knowledge-centered goal setting and have a balanced perspective with pedagogical content knowledge. Also, it is required to introduce a future-oriented perspective such as active integration of information and communication technologies.

[Key words] Teacher Education, Teacher Competence, Objective Statements, General Pedagogical Knowledge, Pedagogical Content Knowledge

Contributed: March 15, 2021, Revised:April 13, 2021, Accepted: May 3, 2021

* This work was supported by the author's sabbatical research grant from Daegu Catholic University in 2017. 


\section{Introduction}

In recent decades, the world has witnessed an intensified interest in teacher competence and teacher education (henceforth TE) in connection to a worldwide wave of cross-national and international comparative research on globalized education (Darling-Hammond, 2017; Payne, Blömeke \& Aydarova, 2016). The most prominent trend is the interest in the measuring the attainment of so-called 21 st-century skills, manifested by tests like PISA (Program for International Student Assessment) and PIRLS (Progress in International Reading Literacy Study).

Although English, which is the interest of this study, has not been included in PISA tests so far, South Korea (henceforth Korea) and Finland are high achievers in mathematics, reading, and science. These outstanding achievements in PISA are regarded as a result of successful TE by many educators. The respect for the teaching profession is high in both countries, and the current research-based approach to educating teachers is appreciated. A link between the teachers' status in society and the children's performance in school as measured by PISA was shown by the Global Teacher Status Index 2018, having polled over 40,000 people across 35 countries. Differences also exist. The population, cultural and socio-political contexts, the framework of teacher development, and rankings in the English proficiency index are different, to name a few. Finland ranks in the third place of the English proficiency index among 100 countries and regions, while Korea ranks around the thirties (EF EPI 2020). The status of English as a Lingua Franca (ELF) is also taken differently in both countries. In Finland, ELF features have already been incorporated into English teaching materials, while discussions of the methods and the levels are still underway in Korea. In these circumstances, it will be meaningful to explore and compare the English teacher education systems of both countries.

While a moderate amount of international comparative research exists on long-term TE programs, studies on the courses to be taken are few. 
Furthermore, few studies have focused on the relationship between course objectives and teacher competence. In this study, we compare the teacher competence aimed at in both countries' TE programs. We use objective statements in syllabi in each context to show the differences and the similarities of two English TE programs and raise awareness of their specific features to improve the quality of the programs. By analyzing course objectives, we can gain insight into professional teacher competencies and the expectations for the teachers in each country.

\section{Theoretical Background}

\section{Competence as an Action-Based Construct}

In this study, the fundamental notion of competence is employed as a dynamic entity of knowledge, skills, and dispositions. These aspects are transversal and may intermesh and overlap, and also they enable the teacher to act appropriately in complex situations (Caena, 2013; Piccardo $\&$ North, 2019). Competence refers to the overall ability to act as a teacher and incorporate a philosophical aspect of responsibility and emotional engagement to promote students' growth.

Another distinction worth mentioning is the extensive use of the term 'teacher knowledge' when referring to the triad of knowledge, skills, and competence (Carlsen, 1999; Shulman, 1987). In the current study, we keep these three areas apart and only use the term and construct of knowledge concerning cognitive operations and declarative knowledge. When the knowledge presumes action or value-bound considerations, we define the element as a skill or a value. We have yet to recognize the interdependence of the three domains in consonance with research in the field.

Research on teacher competence complies with major conceptualizations regarding learning and teaching (Toom, 2017). The earliest theory of 
teacher learning, the process-product view, was inspired by behaviorism and assumed teaching as a set of actions. It was gradually replaced by the cognitive modeling conceptualization considering teaching as a form of thinking. The most recent trend is the situational and social perspective based on the Vygotskian heritage of socio-culturalism (Johnson \& Golombek 2020). Teaching is interactive, and teacher learning, like all learning, implies changes in interactions within communities (Gitomer \& Bell, 2016).

For this study, we chose to apply a framework proposed by the Council of Europe (Caena, 2013) because it is based on a large array of teacher competence frameworks and has already been recognized in Europe for some time (OECD, 2013: 150). The framework principally consists of three parts: knowledge, skills, and values. The knowledge component of teacher competence is divided into two sub-domains: Pedagogical content (PC) knowledge and general pedagogical (GP) knowledge. PC knowledge refers to subject-specific knowledge about tasks, learning contexts and objectives, knowledge of students' prior knowledge, and recurrent learning difficulties. GP knowledge refers to non-subject-specific knowledge of the teaching and learning process and the curricular knowledge and materials.

The skill-related domain of teacher competence includes various practical skills required for teachers to implement the class (Caena, 2013). This domain encompasses the comprehensive abilities that are neither knowledge nor values, such as planning, managing, monitoring, adapting and assessing, and others. Besides, the abilities to collaborate with colleagues, parents, and social services belong to this domain. The specific components will be shown in Table 2 .

The dispositions and belief components of teacher competence are relevant to beliefs, attitudes, values, and commitment to teaching (Caena, 2013). This domain embraces epistemological awareness, dispositions to change, commitment to promoting the learning of all students, etc. Critical attitudes to one's teaching, the disposition to team-working, collaboration and networking, and sense of self-efficacy pertain to this domain. 


\section{Comparative International Research on $\mathrm{TE}$}

International comparative studies on TE have become a prominent feature in policymaking and related processes, fuelled by the globalized nature of education, which is characterized by increased technological, information and pedagogical transfer (Adamson, 2012; Nguyen, 2013). Since the PISA ranking release, many studies have been conducted to find the distinctive features of $\mathrm{TE}$ in top-ranked countries. The logic behind this tendency assumes that the work of classroom instruction is directly connected with teacher competence.

Many relevant updates on teachers' working conditions, beliefs, and practices are regularly produced by TALIS, the Teaching and Learning International Survey (OECD, 2013), which covers the entire global sphere of education. Those are beyond the scope of our study but deserve to be mentioned because of the theoretical underpinnings that comprise the same purviews of teacher knowledge, skills, and beliefs as our study. Karatsiori (2016) researched to compare French language TE programs in Europe using a theoretical framework analogous to ours.

Finnish TE has been the theme of numerous studies, not least inspired by the worldwide PISA fame in earlier years. Finnish TE has been studied compared with Estonian programs (Jakku-Sihvonen et al., 2012) and in a multi-comparison to TE programs in Canada, Denmark, Finland, and Singapore (Rasmussen \& Bayer, 2014). The impact of TE programs in Norway and Finland was investigated by Afdal (2014). A comparison with an Asian country, Thailand, was made by Vibulphol et al. (2015) to reveal differences in policies and approaches to TE. A comparison between Finnish and Japanese student teachers was carried out by Uematsu-Ervasti (2019) on global perspectives in their teaching.

Most previous comparative studies examined Finnish TE revolve around pedagogy master programs of 4-5 years (so-called class TE), while the one-year pedagogical program for subject teachers has been little examined. A parallel study similar to ours was carried out by Krzywacki, Kim, and 
Lavonen (2017), investigating physics teacher knowledge in Korea and Finland. The results suggest significant differences in national educational cultures, and the Korean physics TE tended to be more theoretically oriented than its Finnish counterpart. On the other hand, in both countries, reflection and research orientation are voiced in pedagogical studies for subject teachers.

In a similar vein, but with a slightly different focus, several studies have examined university coursework to find transnational commonalities and differences in teacher preparation programs. Kim, Ham, \& Paine (2011) examined the official educational aims and curricula of mathematics teacher preparation programs in Korea and the United States. Through the comparative analysis of teaching content, researchers argued that having a balanced perspective by attending to the sociohistorical context helps to assess teacher education better.

Our aim in the current study is to find what is expected from the teachers in two countries, Finland and Korea, and how the expectations differ between the two countries by comparing objectives specified in the coursework syllabi. Unlike earlier studies that focused on teacher knowledge, we examined the teacher education curricula using the teacher competence framework comprising knowledge, skills, and values. To fulfill the aims of the study, we examined how object statements are related to teacher competence domains and course types. Since the study was descriptive, we presented the syllabus objectives as they were.

\section{Research Contexts and Method}

\section{The historical context of TE in Finland and Korea}

In Finland, the teaching profession has been respected for many years. The early years of compulsory basic education in 1970 was defined by centralized control and a striving for uniformity in both the national 
curricula and TE programs. The ethos of centralization started to break down in the 1980s and gave the teachers more space and appreciation in the local decision-making as interpreters of the curriculum. These pursuits were reflected in $\mathrm{TE}$ as increased individuality and reflection that paved the way for the new millennium's mainstream ideal: research-based TE. (Tirri, 2014.)

The last two decades have been characterized by rapid changes in the global economy, mobility of people, and unforeseen cultural encounters. Educating professionals for a highly unpredictable future (Johnson \& Golombek, 2020) takes far more than any TE program can provide. Nevertheless, pedagogical studies aim at offering a sound starting point for a lifelong journey of professional growth rooted in theoretical knowledge, practical skills, and a favorable attitude.

In Korea, teaching is a traditionally respected occupation. Recent economic instability and difficulty finding employment make teaching a stable workplace very attractive to the younger generations. However, becoming a teacher in Korea is not simple. TE in Korea can be broadly divided into primary and secondary school TE. The MOE has regulated the supply of primary school teachers trained in only 13 institutions in the country, whereas it has not closely regulated the supply of secondary school teachers trained in a much broader set of institutions and programs. The number of secondary school preparation programs far exceeds the demand for the teachers. This oversupply of pre-service teachers is one of the complex issues of Korean teacher education.

The MOE superintends teacher preparation programs for primary and secondary school teachers through the curriculum regulations for the teaching certificate. Teaching certificates grant the holders eligibility to teach at schools. However, they must pass the Teacher Employment Examination, which is very competitive.

Teacher qualifications in Korea are primarily theoretical. This theory and knowledge-based education are related to the social expectation of the teachers. Recently, new attempts have been made to complement the 
weak emphasis on-field experience. New requirements, such as First aid \& CPR training and 60 hours of Voluntary teaching activity, were added to the curriculum to strengthen the practical aspects. Also, a new subject, Prevention of school violence and understanding students, was added to the teacher preparation curriculum to meet the expectations of the community. To sum up, the Korean teacher preparation programs have taken constant effort to increase teachers' competencies to cope with the changing schools and society.

\section{A. English TE Program in Korea}

The current English teacher preparation in Korea consists of three preparations as follows: (a) a four-year English major program in the college of education, (b) a four-year English major program in non-college of education with add-on pedagogical courses, and (c) a two-year graduate school of education with an English major.

Although there are varied routes to becoming a teacher in Korea, the qualification and teacher certificate systems are centralized. To be awarded a teaching certificate, student teachers need to meet the credit requirements 1 . Credit requirements for graduation are 140 credits, including a minimum of 50 credits of subject courses, 22 credits of general pedagogical courses, and liberal arts. Most subject courses and subjectdidactic courses are three credits each, while general pedagogical courses are two credits. Recognizing the importance of on-site experience, the MOE increased the practice teaching credit from 2 to 4 since 2009. Out of 4 credits, 60 hours of volunteer teaching activity occupies two credits. A separate system from other courses is applied to teaching practice and volunteer teaching activity in terms of credit. Teaching Practice is a two-credit course, but student teachers are present in all educational events and procedures of training schools 9 to 5. The volunteer teaching

1) One credit is equal to one hour of class time. Usually, a semester continues for 15 weeks in Korea, which gives a three-credit course 45 hours per semester. Unlike Finland, the time of self-study is not counted. 
activity is also assigned two credits, but it corresponds to 60 hours. Still, compared to the Finnish teacher education system, four-weeks of the practicum is relatively short. Table 1 shows the detailed structure of both countries' TE curriculum.

〈Table 1〉 Structure of TE Programs in Finland and Korea

\begin{tabular}{|c|c|c|}
\hline & $\begin{array}{l}\text { University of Helsinki } \\
\text { (Finland) }\end{array}$ & $\begin{array}{c}\text { Daegu Catholic University } \\
\text { (Korea) }\end{array}$ \\
\hline $\begin{array}{l}\text { General courses on } \\
\text { education, } \\
\text { teaching and learning }\end{array}$ & $\begin{array}{l}\text { Psychology of learning and } \\
\text { development } 5 \mathrm{cr} \\
\text { Social, cultural and } \\
\text { philosophical foundations of } \\
\text { education } 5 \mathrm{cr} \\
\text { Learning challenges } 5 \mathrm{cr}\end{array}$ & $\begin{array}{l}\text { Total } 22 \mathrm{cr} \text { including } 4 \mathrm{cr} \\
\text { of compulsory courses } \\
\text { (Understanding special } \\
\text { education and special } \\
\text { needs students, } 2 \mathrm{cr} \\
\text { Understanding the nature } \\
\text { of teaching profession } 2 \mathrm{cr} \text { ) }\end{array}$ \\
\hline $\begin{array}{l}\text { Pedagogical content } \\
\text { knowledge/Subject } \\
\text { didactics/ Subject } \\
\text { knowledge (in the } \\
\text { case of Korean data) }\end{array}$ & $\begin{array}{l}\text { Planning, implementation } \\
\text { and assessment of teaching } \\
10 \mathrm{cr} \\
\text { Curriculum and development } \\
\text { of educational institution } 5 \mathrm{cr}\end{array}$ & $\begin{array}{l}\text { - Over } 50 \mathrm{cr} \\
\text { Including seven mandatory } \\
\text { courses }(21 \mathrm{cr}) \text {, and } \\
\text { three mandatory Pedagogical } \\
\text { content courses (Theoretical } \\
\text { foundations of TEFL, Materials } \\
\text { development in English } \\
\text { teaching, Essay writing on } \\
\text { English education) }\end{array}$ \\
\hline Teaching practice & $\begin{array}{l}\text { Basic Practice incl. } \\
\text { reflection } 10 \mathrm{cr} \\
\text { Advanced practice incl. } \\
\text { reflection } 10 \mathrm{cr}\end{array}$ & $\begin{array}{l}\text { Teaching practice } 2 \mathrm{cr} \\
\text { Voluntary activity in } \\
\text { education } 2 \mathrm{cr}\end{array}$ \\
\hline $\begin{array}{l}\text { Educational research } \\
\text { in subject didactics }\end{array}$ & $\begin{array}{l}\text { Teacher as a researcher } \\
\text { seminar (compulsory, } 10 \mathrm{cr} \text { ) }\end{array}$ & Not required \\
\hline
\end{tabular}

Note. $\mathrm{cr}=$ credit

\section{B. Language TE Programs in Finland}

The education of prospective teachers of modern languages in Finland complies with the subject TE framework comprising 60 credits $(1$ credit = 27 study hours) (See Table 1). The mainstream pre-service student-teacher 
of a foreign language acquires his/her linguistic skills at faculties of arts majoring in the language(s) he/she aims to teach in the future. After two years of language studies, he/she applies to undertake pedagogical studies for subject teachers by passing an interview with two experts in the language and didactics. After an approved interview, the student enters pedagogical studies as her minor subject in the faculty of education. These studies start in autumn and take two semesters, after which she is qualified to teach any school subject that she has taken a sufficient number of credits in. In principle, subject studies of 60 credits are required to work in basic education and advanced studies $(120 \mathrm{cr}$ ) to teach a subject at the upper secondary level. After the pedagogical study year, teacher students customarily return to their home faculty to finalize their master's level, including the pedagogical studies as a component of their master's degree.

The structure of pedagogical studies is based on the alternation of theoretical study units and their practical implementation. Content-wise, they address three main areas: subject didactics (pedagogical content knowledge), general pedagogical knowledge, and practice. All the study units are described in the TE curriculum in terms of objectives, timing, completion methods, contents, and grading. This study draws on the 2017-18 curriculum for English teacher education in a broad outline corresponding to its Finnish counterpart. It is noteworthy that irrespective of the language the students are going to teach in the future, all the instruction at the pedagogical study units is delivered either in Finnish (majority language of the country), Swedish (the second official language of the country), or English (at the specific international program). Finnish language teachers' pedagogical studies only focus on how to teach any language, while no linguistic or language-specific content (such as grammar) is taught in the didactic courses. During the practice periods at teacher training schools, student-teachers are mentored by teachers in their language. 


\section{Data Gathering and Analysis}

For comparison of teacher competence, which the two TE programs aim at2), the documents including English language teaching education curriculums, syllabi, and guides were collected from the universities. The Korean data consists of 10 syllabi from subject didactic courses and the same number of syllabi from general pedagogy courses. The Finnish data comprise 8 study units, five focusing on subject didactics and three on general pedagogy. The documents were sifted through and coded to domains of the teacher competence framework developed by the European Council (Caena, 2013), as shown in Table 2. The primary focus was put on the objectives in the syllabi to identify the characteristics of the courses. For example, the statement 'learn about current research and theories in second language learning' was coded to 'PCK' (Pedagogical Content Knowledge) under the Knowledge and understanding domain. A statement like "be able to apply technology in collaborative knowledge creation' was coded to 'Using teaching materials and technologies' under the Skills domain. Complex statements were split up into their propositional constituents by the main verb. For instance, the objective 'plan, implement and assess their teaching' was categorized as three single statements: 'plan their teaching,' 'implement their teaching,' and 'assess their teaching.

Regarding the reliability and validity of international comparative studies, Afdal (2019) aptly recognizes the benefits of gaining and widening understanding of each other's contexts and priorities. Concurrently, Afdal gives a sound warning against the decontextualized, ahistorical, and standardized transfer of conclusions. In the current study, which was based on two academic programs' stated objectives, we also recognize the dual challenge of interpreting the wordings: at the technical level of analysis and the cultural level of local practical implementation. The first

2) Since we analyzed only one TE program per country, there are limitations in generalizing the results. 
issue has been tackled by cross-checking each other's categorizations and obtaining a reliability coefficient that turned out to be very high, ranging from 0.7 to 1.0 . per category.

The proportion of each category was calculated, and a comparison was made between the two curricula to see whether the courses in the same category aimed at the same teacher competence.

\section{Findings}

In this section, the outcome of the analysis is reported for both countries. We have presented sample sentences here so that differences in the objective statements in the syllabi are revealed through concrete examples.

〈Table 2〉Instances of Objective Statements from Subject Didactic Courses (SDC) and General Pedagogical Courses (GPC) in Both Countries

\begin{tabular}{|c|c|c|}
\hline Domain & Finnish & Korean \\
\hline \multicolumn{3}{|l|}{ Knowledge } \\
\hline $\begin{array}{l}\text { Subject matter } \\
\text { knowledge }\end{array}$ & - none & $\begin{array}{l}\text { - student teachers } \\
\text { develop English reading } \\
\text { skills through English novels } \\
\text { (5) }\end{array}$ \\
\hline \multirow[b]{2}{*}{$\begin{array}{l}\text { Pedagogical Content } \\
\text { Knowledge (PCK) }\end{array}$} & $\begin{array}{l}\text { - consider their own and } \\
\text { others teaching with teachers } \\
\text { and their peer group (4) }\end{array}$ & $\begin{array}{l}\text { - understand the characteristics } \\
\text { of speaking skills (total 12) }\end{array}$ \\
\hline & $\begin{array}{l}\text { - know the values serving as } \\
\text { the basis of the basic } \\
\text { education and upper } \\
\text { secondary education core } \\
\text { curriculum (1) }\end{array}$ & $\begin{array}{l}\text { - understand the teaching } \\
\text { strategies of special } \\
\text { education (1) }\end{array}$ \\
\hline
\end{tabular}

3) We found five instances of objective statements that are targeted at subject knowledge. The examples show the undergraduate-based teacher education system of Korea. Since the focus of the study will be on the features of pedagogical and subject-didactic domains in two countries, the subject matter 
$\langle$ Table 2〉 Continued

\begin{tabular}{|c|c|c|}
\hline Domain & Finnish & Korean \\
\hline \multirow{2}{*}{$\begin{array}{l}\text { Pedagogical } \\
\text { knowledge }\end{array}$} & $\begin{array}{l}\text { - understand didactics as an } \\
\text { area of education and as the } \\
\text { theoretical basis of teachers' } \\
\text { professional knowledge and } \\
\text { skills (2) }\end{array}$ & $\begin{array}{l}\text { - develop their own views on } \\
\text { learning and teaching (2) }\end{array}$ \\
\hline & $\begin{array}{l}\text { - have basic knowledge of the } \\
\text { relationship between } \\
\text { interaction, learning and } \\
\text { behaviour (3) }\end{array}$ & $\begin{array}{l}\text { - understand the goals of } \\
\text { education and the role of } \\
\text { teachers (4) }\end{array}$ \\
\hline \multirow{2}{*}{$\begin{array}{l}\text { Curricular } \\
\text { knowledge }\end{array}$} & $\begin{array}{l}\text { - pedagogically justify } \\
\text { methodical solutions }\end{array}$ & $\begin{array}{l}\text { - review the curriculum } \\
\text { theories (2) }\end{array}$ \\
\hline & $\begin{array}{l}\text { - understand the curriculum } \\
\text { philosophy (3) }\end{array}$ & - none \\
\hline \multirow{2}{*}{$\begin{array}{l}\text { Educational sciences } \\
\text { foundation }\end{array}$} & $\begin{array}{l}\text { - understand the development } \\
\text { of the school and of teaching } \\
\text { as part of their teacherhood } \\
\text { as a subject teacher (1) } \\
\end{array}$ & - none \\
\hline & $\begin{array}{l}\text { - familiarize themselves with } \\
\text { the basic concepts of } \\
\text { educational philosophy }(3)\end{array}$ & $\begin{array}{l}\text { - understand the students } \\
\text { individual variables (10) }\end{array}$ \\
\hline \multirow{2}{*}{$\begin{array}{l}\text { Contextual, } \\
\text { institutional, } \\
\text { organizational } \\
\text { aspects of } \\
\text { educational policies }\end{array}$} & - none & - none \\
\hline & $\begin{array}{l}\text { - understand the effect of the } \\
\text { growth and education } \\
\text { environment (4) }\end{array}$ & $\begin{array}{l}\text { - understand the current } \\
\text { Korean National Curriculum } \\
\text { and its changes (5) }\end{array}$ \\
\hline \multirow[b]{2}{*}{$\begin{array}{l}\text { Issues of inclusion } \\
\text { and diversity }\end{array}$} & $\begin{array}{l}\text { - recognize diverse learners in } \\
\text { interactive situations }(2)\end{array}$ & -none \\
\hline & $\begin{array}{l}\text { - have basic knowledge how to } \\
\text { recognize learning difficulties } \\
\text { and how to support learning } \\
\text { in a day care and school } \\
\text { context (2) }\end{array}$ & $\begin{array}{l}\text { - recognize the causes of school } \\
\text { violence (2) }\end{array}$ \\
\hline \multirow{2}{*}{$\begin{array}{l}\text { Effective use of } \\
\text { technologies in } \\
\text { learning }\end{array}$} & - none & $\begin{array}{r}\text { - critically evaluate technological } \\
\text { tools for language learning (4) }\end{array}$ \\
\hline & $\begin{array}{l}\text { - know the basics of applying } \\
\text { ICT in teaching and studying } \\
\text { (1) }\end{array}$ & $\begin{array}{l}\text { - understand the teaching- } \\
\text { learning relationship and } \\
\text { use of technology effectively (2) }\end{array}$ \\
\hline
\end{tabular}

knowledge category will be excluded from now on. 
$\langle$ Table 2〉 Continued

\begin{tabular}{|c|c|c|}
\hline Domain & Finnish & Korean \\
\hline \multirow[b]{2}{*}{$\begin{array}{l}\text { Developmental } \\
\text { psychology }\end{array}$} & - none & - none \\
\hline & - none & $\begin{array}{l}\text { - understand the students' } \\
\text { physical, psychological and } \\
\text { developmental } \\
\text { characteristics (2) }\end{array}$ \\
\hline \multirow{2}{*}{$\begin{array}{l}\text { Group processes and } \\
\text { dynamics, learning } \\
\text { theories, } \\
\text { motivational issues }\end{array}$} & $\begin{array}{l}\text { - understand the school as a } \\
\text { diverse and multi-professional } \\
\text { community (1) }\end{array}$ & - none \\
\hline & $\begin{array}{l}\text { - be able to be target-oriented } \\
\text { and constructive in interactive } \\
\text { situations (1) }\end{array}$ & $\begin{array}{l}\text { - understand the behaviour of } \\
\text { teenagers within the culture } \\
\text { (2) }\end{array}$ \\
\hline \multirow{2}{*}{$\begin{array}{l}\text { Evaluation and } \\
\text { assessment } \\
\text { processes and } \\
\text { methods }\end{array}$} & $\begin{array}{l}\text { - understand the principles } \\
\text { and types of multifaceted } \\
\text { formative and summative } \\
\text { assessment of learning (2) }\end{array}$ & $\begin{array}{l}\text { - have a better understanding } \\
\text { of L } 2 \text { assessment processes } \\
\text { for different purposes and } \\
\text { contexts (4) }\end{array}$ \\
\hline & $\begin{array}{l}\text { - understand the principles } \\
\text { and types of multifaceted } \\
\text { formative and summative } \\
\text { assessment of learning (2) }\end{array}$ & $\begin{array}{l}\text { - understand the basic } \\
\text { concepts and philosophy of } \\
\text { educational assessment (1) }\end{array}$ \\
\hline \multicolumn{3}{|l|}{ Skills } \\
\hline \multirow{2}{*}{$\begin{array}{l}\text { Planning, managing } \\
\text { and coordinating } \\
\text { teaching }\end{array}$} & $\begin{array}{l}\text { - be able to apply subject } \\
\text { didactical knowledge in } \\
\text { planning, implementing and } \\
\text { assessing teaching (11) }\end{array}$ & $\begin{array}{l}\text { - facilitate students' language } \\
\text { learning through technology } \\
\text { tools (5) }\end{array}$ \\
\hline & $\begin{array}{l}- \text { be able to act } \\
\text { target-orientedly and } \\
\text { constructively in interactive } \\
\text { situations }\end{array}$ & $\begin{array}{l}\text { - apply knowledge about } \\
\text { instructional planning to the } \\
\text { classroom teaching (1) }\end{array}$ \\
\hline \multirow{2}{*}{$\begin{array}{l}\text { Using teaching } \\
\text { materials and } \\
\text { technologies }\end{array}$} & $\begin{array}{l}\text { - utilize ICT to support } \\
\text { learning (3) }\end{array}$ & $\begin{array}{l}\text { - familiarized with diverse } \\
\text { technology resources }(3)\end{array}$ \\
\hline & $\begin{array}{l}\text { - utilize ICT solutions in } \\
\text { teaching (1) }\end{array}$ & $\begin{array}{l}\text { - implement instruction using } \\
\text { ICT (2) }\end{array}$ \\
\hline \multirow[b]{2}{*}{$\begin{array}{l}\text { Managing students } \\
\text { and groups }\end{array}$} & - none & - none \\
\hline & $\begin{array}{l}\text { - recognize methods that } \\
\text { promote an environment that } \\
\text { allows pupils to work } \\
\text { undisturbed (3) }\end{array}$ & - none \\
\hline
\end{tabular}


$\langle$ Table 2〉 Continued

\begin{tabular}{|c|c|c|}
\hline Domain & Finnish & Korean \\
\hline \multirow{2}{*}{$\begin{array}{l}\text { Monitoring, adapting } \\
\text { and assessing } \\
\text { teaching/learning } \\
\text { objectives and } \\
\text { processes }\end{array}$} & $\begin{array}{l}- \text { assess teaching independently } \\
\quad(4)\end{array}$ & $\begin{array}{l}\text { - develop the ability to adapt } \\
\text { their teaching to lesson } \\
\text { objectives (1) }\end{array}$ \\
\hline & $\begin{array}{l}\text { - take diverse learners into } \\
\text { account in interactive } \\
\text { situations }(1)\end{array}$ & $\begin{array}{l}\text { - develop the ability to make } \\
\text { and adapt assessment tools } \\
\text { for school contexts (1) }\end{array}$ \\
\hline \multirow{2}{*}{$\begin{array}{l}\text { Collecting, analysing, } \\
\text { interpreting evidence } \\
\text { and data for } \\
\text { professional decisions } \\
\text { and teaching/learning } \\
\text { improvement, }\end{array}$} & $\begin{array}{l}\text { - analyse and assess the } \\
\text { results of their teaching (1) }\end{array}$ & $\begin{array}{l}\text { - critically appraise existing } \\
\text { L2 tests and assessment (1) }\end{array}$ \\
\hline & $\begin{array}{l}\text { - apply assessment solutions } \\
\text { purposefully (2) }\end{array}$ & $\begin{array}{l}\text { - critically reflect on the } \\
\text { realities of Korean } \\
\text { educational assessment }\end{array}$ \\
\hline \multirow{2}{*}{$\begin{array}{l}\text { Using, developing } \\
\text { and creating research } \\
\text { knowledge to inform } \\
\text { practices }\end{array}$} & - none & $\begin{array}{l}\text { - explore the effective ways of } \\
\text { teaching speaking based on } \\
\text { recent research results }(2)\end{array}$ \\
\hline & $\begin{array}{l}\text { - examine teaching and the } \\
\text { school environment } \\
\text { education (2) }\end{array}$ & - none \\
\hline \multirow[b]{2}{*}{$\begin{array}{l}\text { Collaborating with } \\
\text { colleagues, parents } \\
\text { and social services }\end{array}$} & - none & - none \\
\hline & $\begin{array}{l}\text { - be able to be target-oriented } \\
\text { and constructive in } \\
\text { interactive situations related } \\
\text { to learning difficulties with } \\
\text { learners, colleagues, } \\
\text { experts, and learners } \\
\text { parents/guardians }(1)\end{array}$ & - none \\
\hline \multirow[b]{2}{*}{ Negotiation skills } & $\begin{array}{l}\text { - be prepared to network with } \\
\text { associates and social agents } \\
(1)\end{array}$ & - none \\
\hline & $\begin{array}{l}\text { - use the curriculum as a } \\
\text { pedagogical development tool } \\
\text { of the educational institution } \\
\text { in the multi-professional } \\
\text { work community }(5)\end{array}$ & $\begin{array}{l}\text { - apply the theories on } \\
\text { educational administration } \\
\text { to class management }(1)\end{array}$ \\
\hline \multirow[t]{2}{*}{$\begin{array}{l}\text { Reflective, } \\
\text { metacognitive, } \\
\text { interpersonal skills }\end{array}$} & $\begin{array}{l}\text { - analyze their own and others' } \\
\text { teaching with teachers and } \\
\text { their peer group (4) }\end{array}$ & $\begin{array}{l}\text { - have an opportunity to reflect } \\
\text { on their learning experiences } \\
\text { (2) }\end{array}$ \\
\hline & - none & - none \\
\hline
\end{tabular}


〈Table 2〉 Continued

\begin{tabular}{|c|c|c|}
\hline Domain & Finnish & Korean \\
\hline \multirow{2}{*}{$\begin{array}{l}\text { Adapting to } \\
\text { educational contexts }\end{array}$} & - none & $\begin{array}{l}\text { - have opportunities to apply } \\
\text { and adopt various methods to } \\
\text { the teaching context (1) }\end{array}$ \\
\hline & $\begin{array}{l}\text { - be able to analyse the } \\
\text { historical structures of } \\
\text { educational institutions }\end{array}$ & $\begin{array}{l}\text { - apply the understanding of } \\
\text { students' individual variables } \\
\text { to the classroom teaching }(3)\end{array}$ \\
\hline \multicolumn{3}{|l|}{ Dispositions/Values } \\
\hline \multirow[b]{2}{*}{$\begin{array}{l}\text { Epistemological } \\
\text { awareness, } \\
\text { Teaching skills } \\
\text { through content } \\
\text { transferable skills }\end{array}$} & - none & - none \\
\hline & $\begin{array}{l}\text { - understand the nature of } \\
\text { their subject in general } \\
\text { education] and be able to use } \\
\text { applicable forms of teaching } \\
\text { and working] and to justify } \\
\text { their use in various } \\
\text { situations (1) }\end{array}$ & $\begin{array}{l}\text { - reflect on how they commit to } \\
\text { the development of Korean } \\
\text { education (2) }\end{array}$ \\
\hline \multirow[b]{2}{*}{$\begin{array}{l}\text { Dispositions to } \\
\text { change }\end{array}$} & - none & - none \\
\hline & $\begin{array}{l}\text { - take into account the } \\
\text { maintenance and development } \\
\text { of research-based knowledge } \\
\text { and professional skills in } \\
\text { their teaching (1) }\end{array}$ & $\begin{array}{l}\text { - explore the teacher identity } \\
\text { based on the Korean } \\
\text { educational context (1) }\end{array}$ \\
\hline \multirow{2}{*}{$\begin{array}{l}\text { Commitment to } \\
\text { promoting the } \\
\text { learning of all } \\
\text { students }\end{array}$} & - none & - none \\
\hline & - none & - none \\
\hline \multirow[b]{2}{*}{$\begin{array}{l}\text { Dispositions to } \\
\text { promote students } \\
\text { democratic attitudes } \\
\text { and practices }\end{array}$} & - none & - none \\
\hline & $\begin{array}{l}\text { - act in a professional and } \\
\text { ethical manner in accordance } \\
\text { with legislation on the teaching } \\
\text { sector in a multicultural and } \\
\text { pluralistic environment }\end{array}$ & - none \\
\hline \multirow[t]{2}{*}{$\begin{array}{l}\text { Critical attitudes to } \\
\text { one's own teaching }\end{array}$} & $\begin{array}{l}\text { - use the curriculum as a } \\
\text { pedagogical development tool } \\
\text { of the educational institution } \\
\text { in the multi-professional } \\
\text { work community }(1)\end{array}$ & -none \\
\hline & $\begin{array}{l}\text { - understand the values } \\
\text { serving as the basis of } \\
\text { teaching and education }\end{array}$ & -none \\
\hline
\end{tabular}


$\langle$ Table 2〉 Continued

\begin{tabular}{|c|c|c|}
\hline Domain & Finnish & Korean \\
\hline \multirow{2}{*}{$\begin{array}{l}\text { Dispositions to } \\
\text { team-working, } \\
\text { collaboration and } \\
\text { networking }\end{array}$} & - none & $\begin{array}{l}\text { - encourage team members and } \\
\text { share their ideas on teaching } \\
\text { methods through the } \\
\text { cooperative work (1) }\end{array}$ \\
\hline & $\begin{array}{l}\text { - view teachers as a part of a } \\
\text { multi-professional work } \\
\text { community and as partners } \\
\text { for various associates (1) }\end{array}$ & - none \\
\hline \multirow{2}{*}{ Sense of self-efficacy } & - none & - none \\
\hline & - none & - none \\
\hline Total & 86 & 86 \\
\hline
\end{tabular}

Note. The instance from the first cell in each category comes from SDC, and the one in the second cell comes from GPC. The number in the parentheses shows the frequency.

\section{The Relationship Between Objective Statements and Subject- Didactic and General Pedagogical Competence Domain}

This section reports how the objective statements relate to the subject didactic and general pedagogical competence domains (Table 3). When looking at the knowledge domain, the total absolute number of these category statements is higher in Korea than in Finland (53 vs. 36). Knowledge-related statements in the Korean data count for $65 \%$ of all objective statements. Most knowledge statements belong to the general pedagogy-related competence domain in both countries, topped by 35 Korean statements, which make up $43 \%$ of the Korean data. In Finland, most knowledge objectives $(21,24 \%)$ adhere to general pedagogical competence.

The number of skill objectives in Finland is almost double its Korean counterpart (44 vs. 24). Skill-related statements in the Finnish data (26) count for $30 \%$ of the Finnish objective statements and $16 \%$ of all analyzed statements. The majority of the skill statements in both programs belong to the general pedagogical competence domain: 30\% of Finnish and 23\% of 
Korean statements. Value statements were scarce in both data sets, which suggests an emphasis on a cognitive and practical orientation in both programs.

On the whole, analyzed objective statements show that the two programs tend to focus on different aspects of teacher competence. Cognitive objectives dominate the Korean language TE, while skill orientation dominates its Finnish counterpart.

〈Table 3〉 Frequency Distributions of Objective Statements by Domain and Competence in the Finnish and Korean TE Curricula

\begin{tabular}{c|c|c|c|c|c|c}
\hline domain & $\begin{array}{c}\text { PC-related competence } \\
\text { competence domain }\end{array}$ & \multicolumn{2}{|c}{$\begin{array}{c}\text { GP-related } \\
\text { competence }\end{array}$} & \multicolumn{2}{|c}{ Totals } \\
\hline \hline & Korean & Finnish & Korean & Finnish & Korean & Finnish \\
\hline knowledge & $18(22 \%)$ & $15(17 \%)$ & $35(43 \%)$ & $21(24 \%)$ & $53(65 \%)$ & $36(42 \%)$ \\
\hline skills & $5(6 \%)$ & $18(21 \%)$ & $19(23 \%)$ & $26(30 \%)$ & $24(30 \%)$ & $44(51 \%)$ \\
\hline values & $0(0 \%)$ & $1(1 \%)$ & $4(5 \%)$ & $5(6 \%)$ & $4(5 \%)$ & $6(7 \%)$ \\
\hline Total no. & 23 & 34 & 58 & 52 & 81 & 86 \\
\hline
\end{tabular}

\section{The Relationship Between Objectives and Course Types}

We examined the curricular emphasis given to each domain and each type of knowledge by calculating the percentages of objective statements. Regarding the number of objective statements according to the course type, the Finnish data show a higher percentage of subject didactic courses (74\%) than of general pedagogy courses (26\%) as shown in Table 4, while Korean data shows almost no difference between the course types. Along with the greater number of skill-oriented objectives than knowledgeoriented ones, this shows the inclination towards practical competencies in Finnish TE. 
〈Table 4〉 Frequency Distribution of Objective Statements by Course Type

\begin{tabular}{|c|c|c|c|c|c|c|c|}
\hline & & \multicolumn{3}{|c|}{ Finnish Courses } & \multicolumn{3}{|c|}{ Korean Courses } \\
\hline & & SDC & GPC & Total & SDC & GPC & Total \\
\hline \multirow{2}{*}{ knowledge } & PC-related & $11(13 \%)$ & $0(0 \%)$ & \multirow{2}{*}{$36(42 \%)$} & $17(21 \%)$ & $1(1 \%)$ & \multirow{2}{*}{$53(65 \%)$} \\
\hline & GP-related & $14(16 \%)$ & $11(13 \%)$ & & $7(9 \%)$ & $28(35 \%)$ & \\
\hline \multirow{2}{*}{ skills } & PC-related & $18(21 \%)$ & $0(0 \%)$ & \multirow{2}{*}{$44(51 \%)$} & $10(12 \%)$ & $0(0 \%)$ & \multirow{2}{*}{$24(30 \%)$} \\
\hline & GP-related & $16(19 \%)$ & $10(12 \%)$ & & $5(6 \%)$ & $9(11 \%)$ & \\
\hline \multirow{2}{*}{ values } & PC-related & $0(0 \%)$ & $1(1 \%)$ & \multirow{2}{*}{$6(7 \%)$} & $0(0 \%)$ & $0(0 \%)$ & \multirow{2}{*}{$4(5 \%)$} \\
\hline & GP-related & $5(6 \%)$ & $0(0 \%)$ & & $1(1 \%)$ & $3(4 \%)$ & \\
\hline Total & & $64(74 \%)$ & $22(26 \%)$ & 86 & $40(49 \%)$ & $41(51 \%)$ & $81(100 \%)$ \\
\hline
\end{tabular}

When looking into the details, in the knowledge domain, Finnish subject didactic courses show a higher percentage of GP-related knowledge (16\%) than PC-related knowledge (13\%), although the difference is not substantial. Korean subject didactic courses and general pedagogy courses show high percentages in the corresponding knowledge. Regarding the skill domain, subject didactic courses are more focused than general pedagogy courses on developing the skills in the curriculum of both countries. Finnish subject didactic courses allocate similar percentages to PC-related (21\%) and GP-related skills (19\%), but general pedagogy courses only accommodate objective statements related to general pedagogy. Similarly, several Korean subject didactic courses are aimed at the general pedagogical competencies. Among the objective statements in Korean TE courses, $12 \%$ aim to develop pedagogical content-related skills, and 6\% aim to develop general pedagogy-related skills. In Korean general pedagogy courses, only $11 \%$ of objective statements intend to develop skills. In the value domain, the proportion is tiny in both countries. The difference between the two countries is that value targeted objectives are linked with SDC in the Finnish curriculum, whereas they belong to the category of general pedagogy courses in the Korean curriculum. Figure 1 summarizes the characteristics of the curriculum in the two countries described so far. 

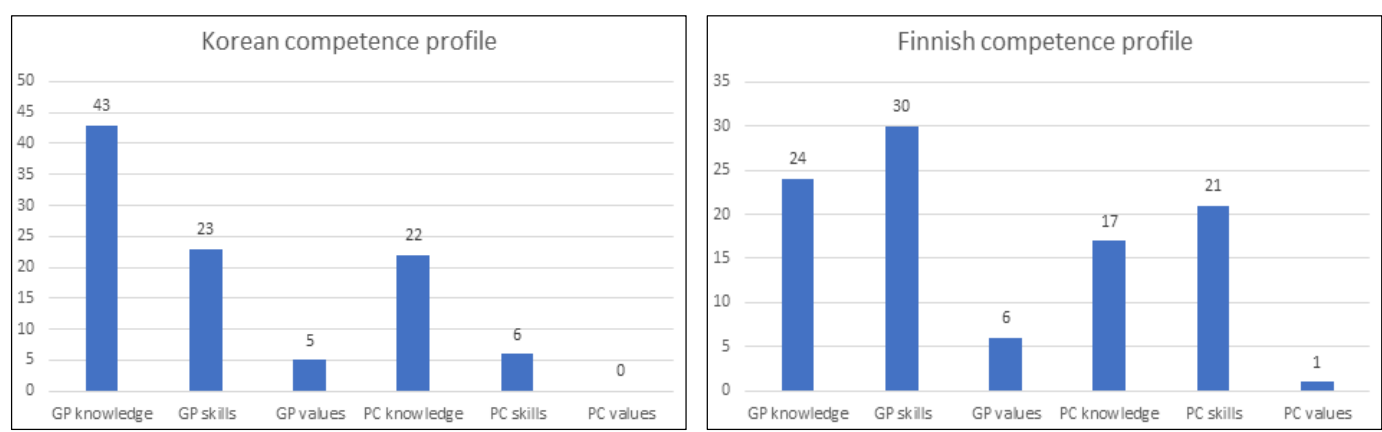

[Figure 1] Teacher Competence Profiles Based on Frequency Distributions of Objective Statements by Domain and Competence in the Finnish and Korean TE Curricula

In the Finnish TE curriculum, subject didactic courses are more in number than general pedagogy courses. This tendency is also shown in a large proportion of the skill domain. On the other hand, Korean subject didactic and general pedagogy courses show almost the same number of objective statements. Considering the different TE systems, the equal weight on the two types of Korean curriculum courses seems valid. Unlike the Finnish TE, Korean TE is provided at the undergraduate level. Thus, the core curriculum for teacher preparation places an equal focus on subject didactic courses, general pedagogy courses, and content-knowledge courses. Another significant difference between the two countries is that the Korean program emphasizes the knowledge domain and on-campus coursework rather than on field-based experience.

\section{Conclusion}

Scrutinizing the course objectives of TE curricula in both countries, we found that objective statements revealed some of the characteristics of the Finnish and the Korean TE curricula. In terms of the competence domain, GP-related competence received more attention than PC-related competence in the data of both countries. In the Finnish data, GP-related 
skill domains such as planning, managing, and coordinating teaching skills occupied the most frequencies while statements on pedagogical content knowledge were less frequent. A prominent characteristic of the Finnish TE curricula was the wide array of GP-related objectives placed in subject didactic courses.

Quite a few Finnish skill statements refer to explorative practice and to consuming and producing research. These echo the intended academic orientation of Finnish TE, which aligns theory and practice with varying grades of success. On the other hand, the role of educational science foundations seems more prominent in the Korean TE.

The inclination towards general pedagogical competence, especially the emphasis on knowledge, looks more distinct in the Korean data. As we discussed above, this could be the main characteristic of the Korean TE, i.e., to provide the knowledge foundations for teaching before developing the skills in the field. Allocation of a single four-week period for teaching practice might indicate the knowledge-centered TE curriculum in Korea. This finding is in line with previous studies (Krzywacki, Kim \& Lavonen, 2017). Korean teacher preparation programs should consider increasing the opportunities to connect the knowledge with skills in authentic situations. Furthermore, Korean TE might need to pay more attention to diversity, reflection, and negotiation skills in multiple professional communities.

Along with overt differences, some similarities were found. The domain of values and dispositions had less importance in the curricula of both countries, although dispositions are fundamental in teacher competencies. It is crucial to acknowledge the role of dispositions in TE, and intentional efforts seem to be necessary to reflect the features of this domain into the curricula.

Not enough attention has been paid to technological competencies considering the role of ICT in the education of the 21 st century and the level of development of ICT industries in both countries. Introducing technology knowledge and skills comprehensively through the foundational 
course from the beginning has been recommended by several researchers (Hegelheimer, 2006). This lack of integration of technologies might also indicate a slow response by teacher trainers to curricula innovations.

Both countries' teacher education needs to balance between knowledge, skills, and disposition, which are large categories of teacher competence, as well as among elements within each domain. In particular, it seems necessary to deviate from the GPK-centered goal setting and have a balanced perspective with PCK. Also, it is required to introduce a future-oriented perspective such as active integration of information and communication technologies. 


\section{References}

Adamson, B.(2012). International comparative studies in teaching and teacher education. Teaching and Teacher Education, 28(5), 641-648.

Afdal, H.(2019). The promises and limitations of international comparative research on teacher education. European Journal of Teacher Education, 42(2), pp. 258-275. doi:10.1080/02619768.2019.1566316

Afdal, H.(2014). Does teacher education matter? An analysis of relations to knowledge among Norwegian and Finnish novice teachers. Scandinavian Journal of Educational Research, 58(3), 281-299. doi:10.1080/00313831.2012.726274

Caena, F.(2013). Supporting teacher competence development for better learning outcomes. European Commission. Education and Training. Retrieved from http://ec.europa.eu/education/school-education/teachercluster_en.htm.

Carlsen, W.(1999). Domains of teacher knowledge. In J. Gess-Newsome \& N. G. Lederman (Eds.), Examining pedagogical content knowledge (pp. 133-144). Dordrecht, Netherlands: Kluwer.

Darling-Hammond, L.(2017). Teacher education around the world: What can we learn from international practice? European Journal of Teacher Education, 40(3), 291-309.

EF EPI (2020). Retrieved from https://www.ef.com/wwen/epi/

Gitomer, D. \& Bell, C.(2016). Handbook of research on teaching. Washington, DC, USA: American Educational Research Association.

Hegelheimer, Volker(2006). When the technology course is required. In P. Hubbard \& M. Levy (Eds.), Teacher education in CALL (pp. 117-133). Amsterdam, Netherlands: John Benjamins Publishing Company.

Jakku-Sihvonen, R., Tissari, V., Ots, A., \& Uusiautti, S.(2012). Teacher education curricula after the Bologna Process- a comparative analysis of written curricula in Finland and Estonia. Scandinavian Journal of Educational Research, 56(3), 261-275. doi:10.1080/00313831.2011. 581687 
Johnson, K. E., \& Golombek, P. R.(2020). Informing and transforming language teacher education pedagogy. Language Teaching Research, 24(1), 116-127. doi:10.1177/1362168818777539

Karatsiori, M.(2016). European profile for language teacher education: Meeting the challenge for sharing common competences, knowledge, strategies and values. Cogent Education, 3(1). 1-29. doi:10.1080/2331186X. 2016.1199125

Kim, R. Y., Ham, S. H., \& Paine, L. W.(2011). Knowledge expectations in mathematics teacher preparation programs in South Korea and the United States: Towards international dialogue. Journal of Teacher Education, 62(1), 48-61.

Korean Ministry of Education.(2019). Practical guidelines for teacher certification. Seoul, South Korea: Ministry of Education.

Krzywacki, H., Kim, B. \& Lavonen, J.(2017). Physics teacher knowledge aimed in pedagogical studies in Finland and in South Korea. EURASIA Journal of Mathematics, Science \& Technology Education, 13(1), 201-222. doi:10.12973/eurasia.2017.00612a

Nguyen, M. H.(2013). The curriculum for English language teacher education in Australian and Vietnamese universities. Australian Journal of Teacher Education, 38(11), 33-53. doi:10.14221/ajte. $2013 \mathrm{v} 38 \mathrm{n} 11.6$

OECD.(2013). Teaching and learning international survey-TALIS 2013. Conceptual framework. Retrieved from: http://www.oecd.org/edu/school/ TALIS\%20Conceptual\%20Framework_FINAL.pdf

Paine, L., Bloemeke, S., \& Aydarova, O.(2016). Teachers and teaching in the context of globalization. In D. Gitomer \& C. Bell (Eds.), Handbook of research on teaching ( $\mathrm{pp}$. 717-786). Washington, DC, USA: American Educational Research Association.

Piccardo, E., \& North, B.(2019). The action-oriented approach: A dynamic vision of language education. New perspectives on language and education 72. Bristol, UK: Multilingual Matters.

Rasmussen, J., \& Bayer, M.(2014). Comparative study of teaching content 
in teacher education programs in Canada, Denmark, Finland, and Singapore. Journal of Curriculum Studies, 46(6), 798-818.

Shulman, L. S.(1987). Knowledge and teaching: Foundations of the new reform. Harvard Education Review, 57(1), 1-22

Tirri, K.(2014). The last 40 years in Finnish teacher education. Journal of Education for Teaching, 40(5), 600-609.

Toom, A.(2017). Teachers' professional and pedagogical competencies: A complex divide between teacher work, teacher knowledge and teacher education. In D. J. Clandinin \& J. Husu (Eds.) The Sage handbook of research on teacher education: 2 (pp. 803-819), London: Sage Publications.

Uematsu-Ervasti, K.(2019). Students' views on increasing global citizenship in Finnish and Japanese teacher education. Unpublished Doctoral Thesis. University of Oulu.

Vibulphol, J., Loima, J., Areesophonpichet, S., \& Rukspollmuang, C.(2015). Ready contents or future skills? A comparative study of teacher education in Thailand and Finland. Journal of Education and Learning, 4(4), 149-159. doi:10.5539/jel.v4n4p149 


\title{
<국문초록>
}

\section{강의 목표 분석을 통한 핀란드와 한국의 영어교사 교육과정 비교}

\author{
이 진 경(대구가톨릭대학교, 꾜수) \\ 라일리 힐든(헬싱키대학표, 부꾜수)
}

[연구목적] 이 연구는 한국과 핀란드의 영어교사 교육과정을 비교하였다. 연구의 목 적은 두 가지로 요약할 수 있다. 첫째, 두 나라의 교사교육에서 추구하는 전문적 교사 역량은 무엇인가 하는 것과 둘째, 그러한 역량이 교육과정에 어떻게 반영되어 있는가를 살펴보았다.

[연구방법] 연구 자료는 두 연구자가 소속된 대학의 교육과정의 교수요목을 분석한 것이다. 특히 지식, 기술, 그리고 품성으로 구성된 교사역량 체계를 기반으로 강좌의 목 표를 분석하였다.

〔연구결과〕 연구 결과, 한국의 교사교육 강좌에서는 기술영역보다는 지식 영역이 더 강조된 반면, 핀란드의 경우에는 기술영역이 강조되는 것으로 나타났다. 이것은 각 대 학의 교육 프로그램이 실제성에 두는 비중이 다른 데에서 비롯된 것으로 보인다. 핀란 드의 영어교사 교육은 다양한 실습 과목에 기술 영역을 통합한 반면, 한국의 영어교사 교육은 실습이 다소 제한적이었다. 교사로서의 가치와 품성 영역은 기본적인 교사의 역 량임에도 불구하고 두 나라의 교사교육 과정에서 중요성이 드러나지 않았다.

[결론] 교사역량을 구성하는 큰 범주인 지식, 기술, 그리고 품성 영역 간의 균형뿐만 아니라 영역 내부의 요소 간에도 균형이 필요하다. 특히 일반 교육학 지식 중심의 강의 목표설정에서 벗어나 세부적인 교과교육학 지식과의 균형있는 관점이 필요해 보인다. 또한 정보통신 기술의 적극적인 통합과 같은 미래지향적인 관점의 도입이 필요하다.

〔주제어〕 교사교육, 교사역량, 목표 기술, 일반교육학 지식, 교과내용 지식 